\title{
Difficulties in maintaining shaft lining - testing methods and repair methods - a case study
}

\author{
Zbigniew Niedbalski ${ }^{1}$, and Piotr Małkowski ${ }^{1 *}$ \\ ${ }^{1}$ AGH University of Science and Technology, Department of Geomechanics, Civil Engineering and \\ Geotechnics, 30 Mickiewicza Ave., 30-059 Kraków, Poland
}

\begin{abstract}
The paper performs the standards of shaft lining inspections used in Poland. They comprised four criterions: lining homogeneity, level of its corrosion, watertightness and load bearing capacity of the lining and the limit values for every criterion were worked out. If even one of above criterion is not met the repair works have to be taken. The example of shaft investigation and technical recommendations for the lining repair is shown as well. It is proved that only a comprehensive approach to the condition of the shaft lining can allow proper assessment of its performance for the next years.
\end{abstract}

\section{Introduction}

In underground mining, shafts are the most important capital items due to their exceptional importance in the process of obtaining raw materials. In almost every underground mine in Poland, shafts are the only way to access deposits, transport people and materials, and serve for ventilation. Each hard coal mine in Poland has several or even a dozen shafts in its area, as making deposits available through audits is very rare. Due to the high excavation costs, the long lifetime and the need to ensure the highest level of safety, the entire process of shaft sinking is subject to extremely thorough and detailed control.

The construction of shafts in various geological conditions in Poland has a long tradition. Over the period of 1945 - 1989 over $260 \mathrm{~km}$ of shafts for excavation of mainly hard coal and copper ores were constructed in Poland [1]. Many shafts that have been deepened due to the need to provide extraction levels at ever-increasing depths should be added to this. Due to the restructuring of the hard coal mining industry, many shafts underwent the decommissioning process [2]. However, this does not change the fact that subsequent implemented investments bring new challenges and the need for unusual technical solutions. When sinking a shaft from the surface, the greatest threat to its stability is the occurrence of a high thickness of the overburden in the form of clays with low geomechanical parameters and watered loose soils. In the case of deep shafts in hard rocks, difficulties result from such factors as: occurrence of salt formations, high depth, tectonic disturbances, local weakness of the rock mass, groundwater, impact of exploitation, seismic activity and intense stratification of strongly inclined layers [3-8].

\footnotetext{
*Corresponding author: malkgeom@agh.edu.pl
} 
The basic technologies used for shaft sinking is the mechanical mining in cohesive soils, while in hard rocks the excavation involving explosives [9]. In the case of very strong rocks and a small depth, a shaft can be unsupported [10]. In the case of weak and watered rocks, the shaft sinking is carried out after freezing the rock mass $[1,11,12]$, but it is then necessary to make a lining, preferably yielding, allowing to absorb stresses after defrosting of rocks [13].

In the conditions of Polish mines, lining protected all shafts. The design of the lining is carried out in accordance with the Polish standard PN-G-05015 [14]. According to the provisions contained therein, the lining in the shafts is made of brick, bentonite, concrete, reinforced concrete, tubing and reinforced concrete panels. For waterproofing, PVC and PE films, tightly connected reinforced concrete or steel panels and sprayed chemicals can be used. Anchors and steel arches are also commonly used to secure underground excavations [15]. In Polish mining conditions, such techniques are also used to reinforce shafts $[16,17]$.

This article presents scope of tests that are performed to assess the stability of shaftlining and describes an assessment example of the shaft stability and the implementation of repairs of lining that has been damaged due to changes in hydrological and mining conditions. During the shaft operation there are additional lining loads or other phenomena not taken into account during design and construction of a shaft, hence after some time shaft lining need to be repaired. Failure to undertake appropriate tests in a relevant time and the lack of measures to secure the lining may result in a construction disaster. Fig. 1 shows a photo from a catastrophe that occurred in one of the mines in the Upper Silesian Coal Basin (USCB) in 2009. At that time, the hoisting tower and accompanying buildings were subject to total destruction (in Fig. 1 the tower's wheels are visible only) and the shaft itself was destroyed to a depth of several dozen metres below ground level. On the surface around the shaft, a sinkhole has been created with a diameter of approx $70 \mathrm{~m}$.

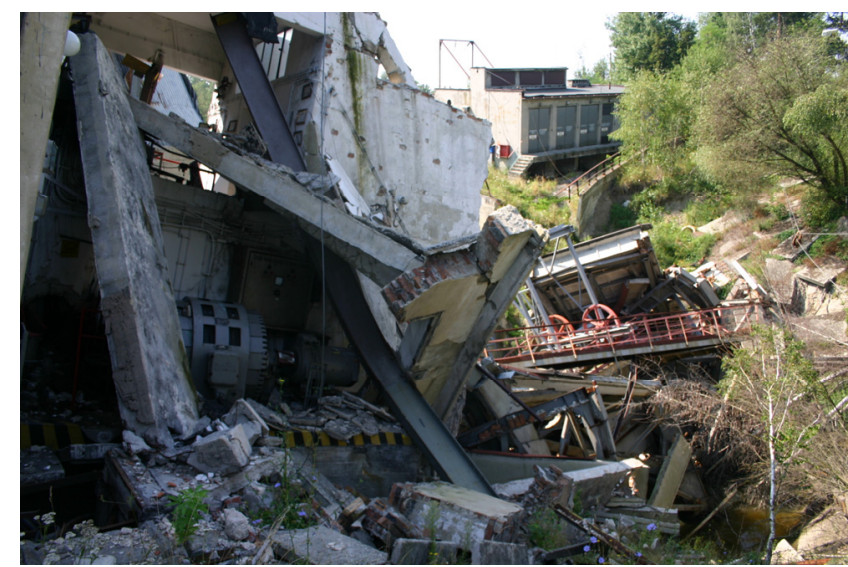

Fig. 1. The picture from the sinkhole formed at the location of the shaft.

\section{Test methods for shaft lining in Poland}

In Polish underground mines, shaft lining tests are carried out in accordance with PN-G04211:1996. The concrete lining of the shaft shall meet four criteria that define this standard. These are:

- the concrete homogeneity criterion determined on the basis of the coefficient of variation of compressive strength (quotient of the standard deviation to the average value), where the homogeneity depending on this parameter is divided into five classes: very good, 
good, average, sufficient and insufficient; this criterion should be met at least to a sufficient degree (Table 1);

- the corrosion criterion determined by the thickness of the corroded concrete layer; the condition of the lining in this case may be good, acceptable and unacceptable, and the limit value permitting use is corrosion of not more than $20 \%$ of the lining thickness and more than $12 \mathrm{~cm}$ (Table 2); the lining meets the corrosion criterion if its condition is at least acceptable;

- the lining's watertightness criterion determined by the permissible water inflow to the bottom of the shaft; the lining meets this criterion if the total water inflow does not exceed $5 \mathrm{dm}^{3} / \mathrm{min}$ from each of the inventoried leaks, and the total water inflow to the shaft sump does not exceed $150 \mathrm{dm}^{3} / \mathrm{min}$ (this amount does not include water included in the drainage system, e.g. gutter drip-pipes and pipelines);

- the load capacity criterion, when the lining gives the possibility to transfer the stresses acting on the shaft lining; the so-called permissible stresses $\sigma_{o c}$ absorbed by the lining wall must be greater than the calculated reduced stresses $\sigma_{\text {red }}$, i.e. the value of the stress transfer reliability coefficient $n=\sigma_{o c} / \sigma_{\text {red }}$ is greater than or equal to one (Table 3 ).

Table 1. The concrete homogeneity criterion of the shaft lining.

\begin{tabular}{|c|c|c|}
\hline \multirow{2}{*}{ Concrete homogeneity } & \multicolumn{2}{|c|}{ Coefficient of variation $v_{r}$} \\
\cline { 2 - 3 } & Concrete up to C20/25 class & Concrete min. C25/30 class \\
\cline { 2 - 3 } & \multicolumn{2}{|c|}{$\%$} \\
\hline very good & $v_{r} \leq 10$ & $v_{r} \leq 7$ \\
\hline good & $10<v_{r} \leq 13$ & $7<v_{r} \leq 10$ \\
\hline average & $13<v_{r} \leq 16$ & $10<v_{r} \leq 13$ \\
\hline sufficient & $16<v_{r} \leq 20$ & $13<v_{r} \leq 15$ \\
\hline insufficient & $>20$ & $>15$ \\
\hline
\end{tabular}

Table 2. The corrosion criterion.

\begin{tabular}{|c|c|}
\hline \multirow[t]{2}{*}{ Lining condition due to corrosion } & $\begin{array}{c}\text { Thickness of corroded concrete layer in relation to lining } \\
\text { thickness }\end{array}$ \\
\hline & $\%$ \\
\hline good & $\leq 10$ but not more than $6 \mathrm{~cm}$ \\
\hline acceptable & $10 \div 20$ but not more than $12 \mathrm{~cm}$ \\
\hline unacceptable & $>20$, more than $12 \mathrm{~cm}$ \\
\hline
\end{tabular}

Table 3. Load capacity criterion of the shaft lining.

\begin{tabular}{|c|c|}
\hline $\begin{array}{c}\text { Degree of the threat to the operational } \\
\text { security of the shaft }\end{array}$ & Value of the stress transfer reliability coefficient $n$ \\
\hline I - safe & $\geq 1$ \\
\hline II - conditionally acceptable & $1 \div 0.75$ \\
\hline III - dangerous & $<0.75$ \\
\hline
\end{tabular}

Concrete linings protect the vast majority of shafts existing in the Polish mining industry. In the case of lining made of concrete blocks or bricks, the same guidelines are most often used, slightly adjusting the coefficient values. Lining tests are performed by destructive and non-destructive methods, and the most important in this respect are the standards PN-EN-12504 [18-21]. A detailed description of strength tests performed on samples with ultrasound, the Schmidt hammer and the pull-off method is described in [22], and additional measurement techniques in [23]. 


\section{The results of shaft no VII lining test}

A small section of the shaft lining was analysed, i.e. $80-110 \mathrm{~m}$ completed in 1987 . The shaft has a diameter of $7.5 \mathrm{~m}$, depth of $543.5 \mathrm{~m}$ and serves as a ventilation shaft. The shaft has an artificial bottom at a depth of $390 \mathrm{~m}$. The shaft VII profile in the depth range from 80 to $110 \mathrm{~m}$ contains tertiary formations developed as alternating layers of fine-grained sand, clay, loam and silty clay. The tertiary formations generally are dipping at an angle of 5 to $10^{\circ}$ to the west. On this section, the lining had the parameters contained in Table 4 .

Table 4. Type of lining on the tested section $80-110 \mathrm{~m}$.

\begin{tabular}{|c|c|}
\hline Dimensions & Type of lining \\
\hline $80.0 \mathrm{~m}-82.0 \mathrm{~m}$ & $\begin{array}{r}\text { final lining } 0.5 \mathrm{~m} \text { thick of } \mathrm{C} 12 / 15 \text { concrete, PE film, preliminary lining of } \\
0.25 \mathrm{~m} \text { thick reinforced concrete panels, }\end{array}$ \\
\hline $82.0 \mathrm{~m}-106.0 \mathrm{~m}$ & $\begin{array}{r}\text { final lining } 0.6 \mathrm{~m} \text { thick of } \mathrm{C} 20 / 25 \text { concrete, PE film, preliminary lining of } \\
0.25 \mathrm{~m} \text { thick reinforced concrete panels, }\end{array}$ \\
\hline $82.0 \mathrm{~m}-106.0 \mathrm{~m}$ & $\begin{array}{r}\text { final lining } 0.7 \mathrm{~m} \text { thick of } \mathrm{C} 20 / 25 \text { concrete, PE film, preliminary lining of } \\
0.25 \mathrm{~m} \text { thick reinforced concrete panels, }\end{array}$ \\
\hline
\end{tabular}

On this section a gap in the lining, among others, was found ( $80 \mathrm{~m}-$ Fig. 2$)$ and high water pressure of $0.6-0.7 \mathrm{MPa}$ (Fig. 3). The water pressure measurement point behind the lining located at a depth of about $56 \mathrm{~m}$ indicated a pressure of $0.20 \div 0.26 \mathrm{MPa}$. The above indicates a combination of aquifers, and thus the additional load on the shaft lining not taken into account when constructing the shaft.

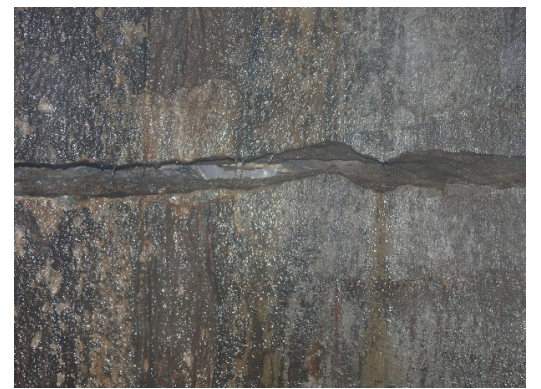

Fig. 2. Gap in the lining with visible waterproofing.

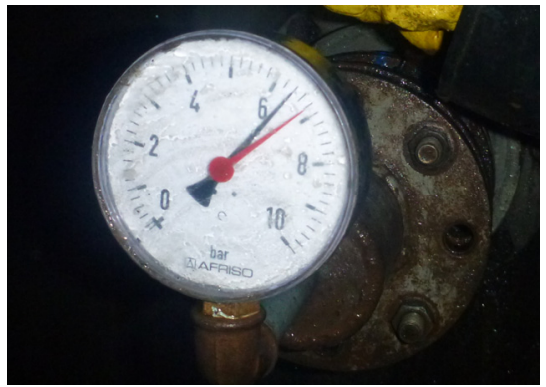

Fig. 3. Water pressure $0.64 \mathrm{MPa}$ behind the shaft lining at the depth of $96 \mathrm{~m}$.

In view of that situation, an analysis was carried out in line with the requirements set out in Chapter 2.

The analysis of the concrete homogeneity criterion of the shaft VII lining was based on sclerometric method. The concrete of the lining used according to the design is C12/15 on the section $80 \div 82 \mathrm{~m}$ and $\mathrm{C} 20 / 25$ on the section $82 \div 110 \mathrm{~m}$. The conducted analyses showed $110 \mathrm{~m}$ section is $16.10-22.52 \mathrm{MPa}$. In the light of the above, it has to be concluded that the concrete homogeneity criterion is met to a very good extent, as the coefficient of variation for the sections mentioned is 0.36 and 8.90 , respectively.

The corrosion degree was determined on the basis of inventories and Sclerometric tests. Observations of the cores taken from the lining were also used. During the inventory it was found that the corrosion criterion was met along the entire length of the shaft. Local cavity areas did not exceed $5 \mathrm{~cm}$ (Fig. 4). Inside concrete, corrosive processes were observed to a depth of approx. $10 \mathrm{~cm}$, which is not more than $20 \%$ of the lining thickness. Thus, due to the corrosion degree, the condition of the lining was found to be sufficient. 
Water leaks were observed around the perimeter of the shaft (Fig. 5) Analyzing in the period from June 2012 to February 2017 the total inflow of water to shaft VII at the level of artificial bottom, i.e. $390 \mathrm{~m}$, it was found that it changes in the range of $0.041 \div 0.194 \mathrm{~m}^{3} / \mathrm{min}$. In the period from the beginning of 2014 the amount of water flowing into the shaft does not exceed 0.150 artificial bottom, i.e. $390 \mathrm{~m}$, it was found that it changes in the range of $0.041 \div 0.194 \mathrm{~m}^{3} / \mathrm{min}$. Therefore, it was concluded that according to the standard, the watertightness criterion in the shaft VII is met.

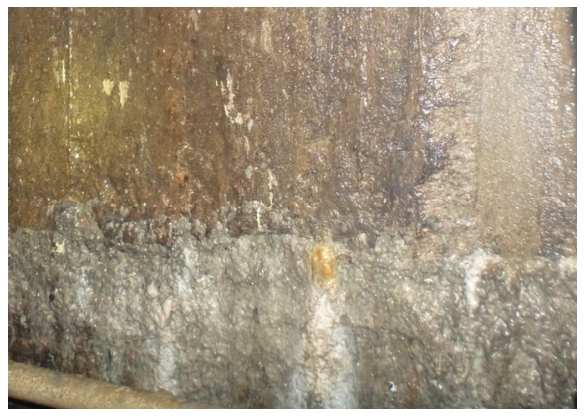

Fig. 4. Corroded part of the lining.

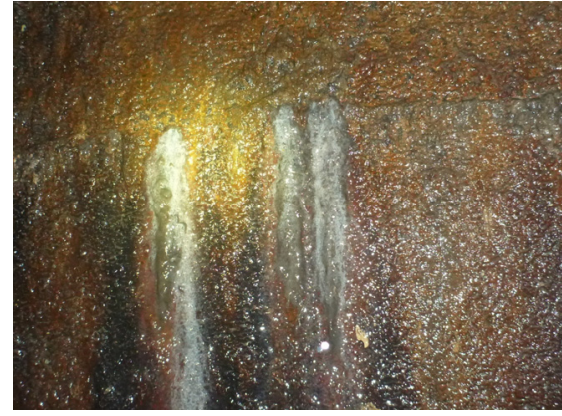

Fig. 5. Water leakage from technological connection.

The last criterion tested for the shaft lining was the load capacity criterion. According to PN-G:04211:1996 standard, the stress transfer reliability coefficient $n$ is determined from the formula:

$$
n=\frac{\sigma_{o c}}{\sigma_{r e d}},
$$

where $\sigma_{o c}$ is permissible stress in the shaft lining, which is taken as the design strength of the lining material, $\mathrm{MPa} ; \sigma_{\text {red }}$ is reduced stress in the shaft lining, determined for current loads and for the current state of lining deformation, MPa.

Calculations of stresses acting on the shaft VII lining and permissible stresses were made based on the geological profile of rocks along the shaft and on the test results of the lining parameters, including primarily the strength of the shaft lining and its thickness. Calculations indicate that the maximum stress value is $1.6 \mathrm{MPa}$ and occurs at a depth of $106.5 \mathrm{~m}$. Almost over the entire analyzed section of the shaft, the lining loads exceed 1 MPa (Fig. 6) and this is the result of the assumed water pressure behind the lining. Such calculations can also be performed numerically [16].

The following assumptions have been made to determine the stress transfer reliability coefficient $n$ :

- the calculated strength of the shaft lining at selected sections was adopted based on the core destruction tests of the lining samples and on tests performed with the Schmidt hammer;

- reduced stress $\sigma_{\text {red }}$ was determined as follows:

$$
\sigma_{\text {red }}=\sqrt{3\left[\frac{r_{w}^{2} \cdot r_{z}^{2} \cdot p}{\left(r_{z}^{2}-r_{w}^{2}\right) \cdot r_{z}^{2}}\right]^{2}},
$$

where $r_{w}$ is inner radius of the shaft, $\mathrm{m} ; r_{w}$ is outer radius of the shaft, $\mathrm{m} ; p$ is calculated load of shaft lining (MPa). 
Based on the results of calculations of the stress transfer reliability coefficient $n$, it was found that over the definite length of section $80 \div 110$ of shaft VII, the stress can reach $1.5 \mathrm{MPa}$ or even more depending of the depth and the rock type around the shaft pipe (Fig. 6). Taking into consideration the lining conditions, value of the load coefficient is usually within $0.76-1.1$ (Fig. 7). However limits of load capacity criterion of the shaft lining (Table 3) shows that load coefficient equals 0.75 or less raises a threat to the operational security of the shaft.

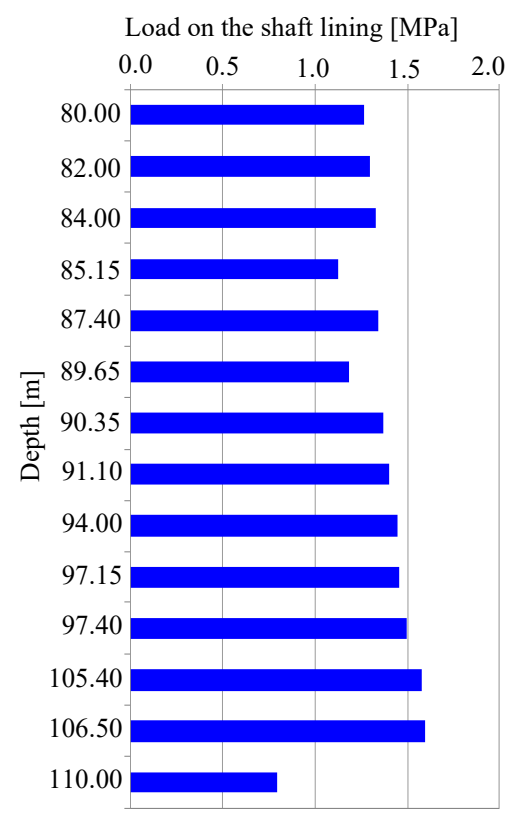

Fig. 6. Loading of shaft VII lining along $80-$ $110 \mathrm{~m}$ section.

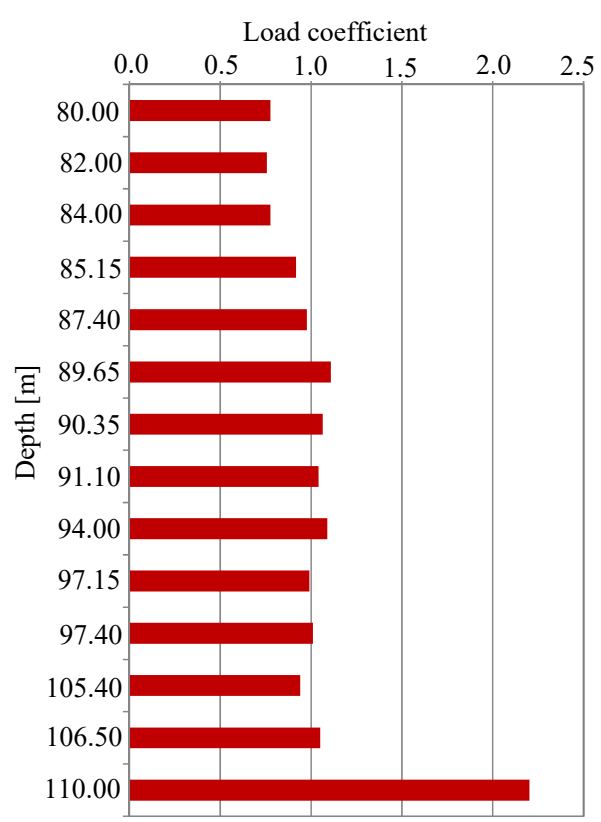

Fig. 7. Value of the stress transfer reliability coefficient through the shaft VII lining over a distance of $80-110 \mathrm{~m}$.

On the basis of the foregoing, it is concluded that the load capacity criterion for the section under test is met to an acceptable extent assuming no water hazard. Any water inflow and additional stress can make the situation worse. Hence, these data indicate that the lining carries loads in the upper stress range and therefore lining needs to be reinforced.

\section{Shaft lining reinforcement design}

The design calculations were made in the Robot Structural program, assuming the reinforcement in the form of galvanized steel rings from the $\mathrm{C} 300$ profile. It has been assumed that such a lining bolted and sealed at the joints with a lead sheet, and additionally laid on a waterproofing membrane on the existing concrete layer, will allow for tightness of the structure. This is particularly important in the event of a concrete leak due to the heavy load on the water behind the lining.

The entire lining with a diameter of 7.45 was divided into 36 sections and the appropriate material properties were defined - profile type and steel type (Fig. 8). In the calculations, coefficients for flexural buckling and lateral torsional buckling were assumed to be 1.2. The maximum load value was at $152 \mathrm{kN} / \mathrm{m}$ (Fig. 9). 
Because there are 3.33 rings per 1 linear metre shaft lining reinforcement, the load capacity of the structure per 1 meter is $506 \mathrm{kN} / \mathrm{m}^{2}$. This value is only slightly lower than the pressure caused by the water in the vicinity of the shaft lining.

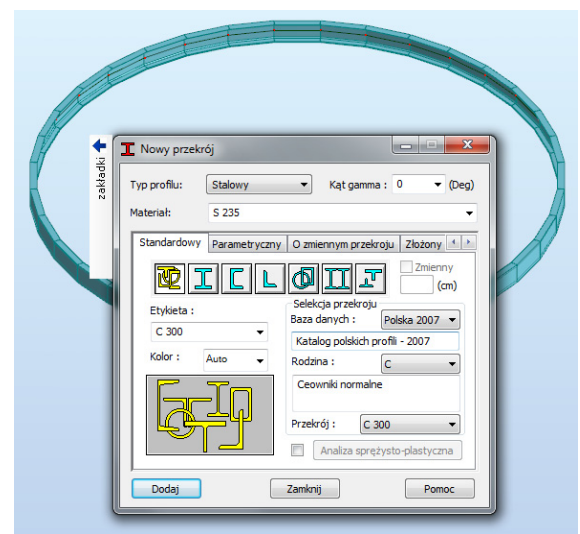

Fig. 8. Data used to calculate the resistance of steel rings.

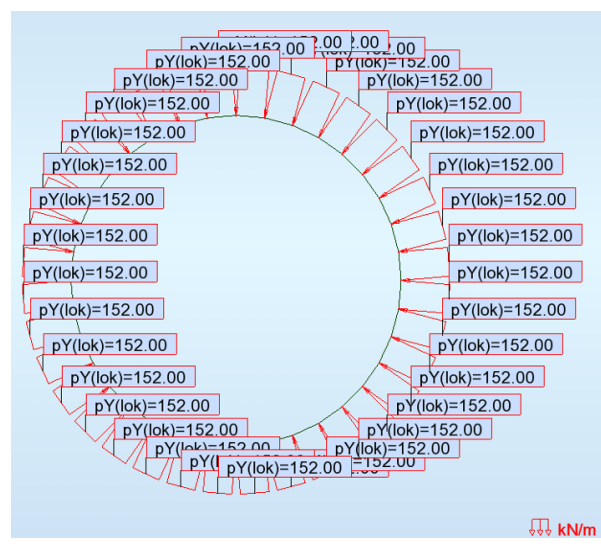

Fig. 9. Maximum load capacity for a single ring.

Each steel lining ring consists of nine twisted segments (Fig. 10). The steel lining rings were anchored to the shaft refractory. To ensure the tightness of the steel lining, bolting with lead gaskets connected the rings. The shaft lining on the section from 80 to $110 \mathrm{~m}$ depth was protected with a waterproofing membrane against the installation of steel rings (Fig. 11). The space between the steel rings and the existing lining was filled with mineralcement binder.

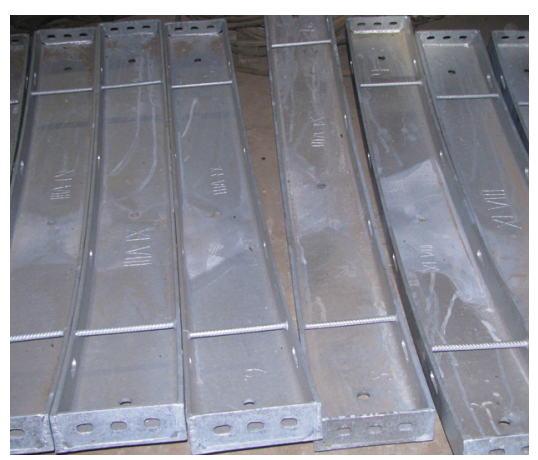

Fig. 10. Galvanized steel rings ready for installation.

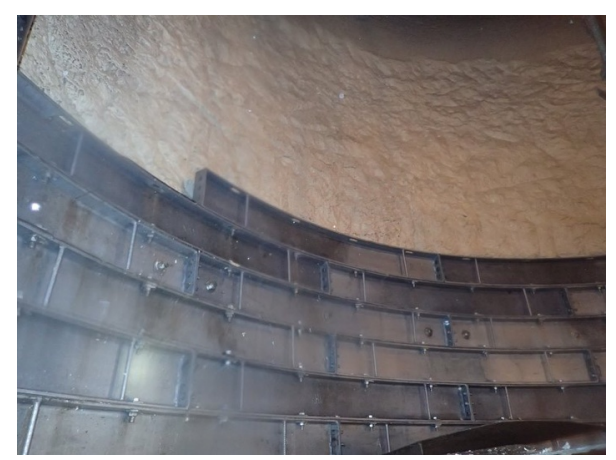

Fig. 11. General view of the steel rings mounted in the shaft on a waterproofing layer.

Due to a damage to the lining, other reinforcements were made in the analyzed shaft, the range of which is shown in Fig. 12 [24]. The most important elements increasing the load capacity of the lining include filling the voids behind the lining with mineral-cement binder, reconstruction of the shaft lining in the places of the largest cracks (Fig. 13), reinforcing anchoring (Fig. 14). 


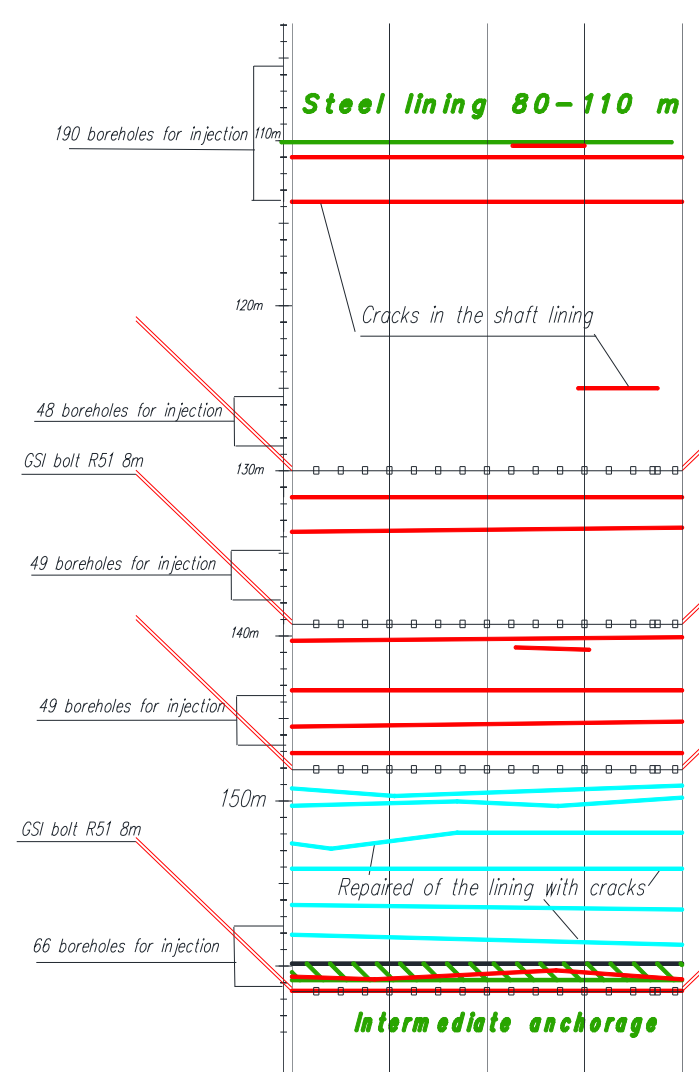

Fig. 12. Diagram of shaft lining reinforcements over a distance of less than $110 \mathrm{~m}$.

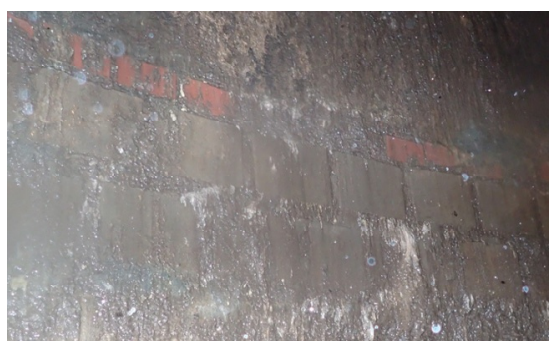

Fig. 13. Repair with the shaft bricks.

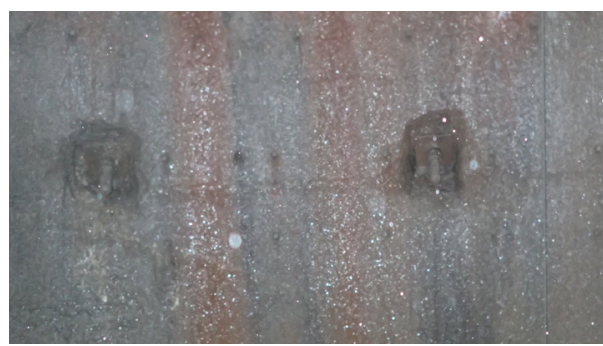

Fig. 14. Anchoring to strengthen the shaft lining.

\section{Conclusions}

For long-term excavations, such as shafts, regular assessment of shaft pipe stability is necessary and should be performed at least once a year. If the shaft is sinked in fault zones or weak layers of low thickness, tests should be more frequent. The assessment of the stability of the shaft pipe cannot only concern the strength of the lining wall itself, but should focus on the uniformity of the wall strength as well. In such case, three aspects are important:

- the variability of the wall strength along the lining length;

- the degree of its corrosion (including the size of water inflow to the shaft and the chemical composition of waters); 
- the current load capacity of the lining in relation to radial stresses, taking into account their changes due to the changing hydrological or mining situation.

Only a comprehensive approach to the condition of the shaft lining can allow proper assessment of its performance for the next months and years. Additionally, hydrogeological and geophysical monitoring can be performed.

In the case of cataloged damages, the lining must be restored to a condition that provides the required load capacity in relation to the calculated loads. For this purpose, mineral-cement binders and steel components can be used (e.g. susceptible or rings arches), anchors or prefabricated elements (panels, blocks, etc.). If no engineering action is taken when insufficient load capacity of the shaft lining is found, a construction disaster may occur in a short period of time, excluding one or several areas of the mine from operation for several months, which will limit production.

\section{References}

1. Wichur, A. (2007). Uwagi o projektowaniu technologii zamrażania górotworu dla potrzeb głębienia szybów. Górnictwo i Geoinżynieria, (3), 447-458.

2. Czaja, P. (2010). Ocena rozwiązań projektowych likwidacji szybów zastosowanych w procesie restrukturyzacji polskiego górnictwa węglowego. Budownictwo Górnicze i Tunelowe, (3), 37-51.

3. Sadaghiani, M.H., \& Bieniawski, Z.T. (1990). Geotechnical design of mine shafts. In 31th U.S. Symposium on Rock Mechanics (pp. 823-830). Golden, Colorado.

4. Bruneau, G., Tyler, D., Hadjigeorgiou, J., \& Potvin, Y. (2003). Influence of faulting on a mine shaft - a case study: part I - Background and instrumentation. International Journal of Rock Mechanics and Mining Sciences, 40(1), 95-111. https://doi.org/10.1016/s1365-1609(02)00115-6

5. Ortlepp, W.D., Joughin, W.C., Ward, A.K., \& Thompson J. (2008). Reinforcement support of concrete shaft lining in Westonaria formation lava in the Ezulwini vertical shaft system. In 6th International Symposium on Ground Support in Mining and Civil Construction (pp. 561-580). Cape Town, South Africa.

6. Walton, G., Kim, E., Sinha, S., Sturgis, G., \& Berberick, D. (2018). Investigation of shaft stability and anisotropic deformation in a deep shaft in Idaho, United States. International Journal of Rock Mechanics and Mining Sciences, (105), 160-171. https://doi.org/10.1016/j.ijrmms.2018.03.017

7. Kovalevs'ka, I., Vivcharenko, V., \& Snigur, V. (2013). Specifics of percarbonic rock mass displacement in longwalls end areas and extraction workings. Annual Scientific-Technical Colletion - Mining of Mineral Deposits, 29-34. https://doi.org/10.1201/b16354-6

8. Pivnyak, G., Bondarenko, V., \& Kovalevska, I. (Eds.). (2015). New Developments in Mining Engineering 2015. London, United Kingdom: CRC Press, Taylor \& Francis Group. https://doi.org/10.1201/b19901

9. Hartman, H.L. (ed.) (1992). SME Mining Engineering Handbook. Society for Mining, Metallurgy, and Exploration. Sacramento, California: Society for Mining, Metallurgy, and Exploration.

10. Pariseau, W.G. (2007). Design Analysis in Rock Mechanics. Taylor \& Francis Group.

11. De la Vergne, J. (2003) Hard Rock Miner's Handbook. 3rd Edition. McIntosh Engineering. North Bay. Ontario, Canada.

12. Tao, H., Weihao, Y., Zhijiang, Y., Chi, Z., \& Dongliang, B. (2011). Monitoring Study of Shaft Lining Concrete Strain in Freezing Water-Bearing Soft Rock During Mine Shaft Construction Period in West China. Procedia Engineering, (26), 992-1000. https://doi.org/10.1016/j.proeng.2011.11.2266

13. Hegemann, J. (1981). A new concept for sinking freeze shafts into great depths. Engineering Geology, 18(1-4), 385-393. https://doi.org/10.1016/0013-7952(81)90076-4

14. PN-G-05015. (1997). Szyby górnicze - obudowa - Zasady projektowania.Warsaw: Polski Komitet Normalizacyjny. 
15. Majcherczyk, T., Małkowski, P., \& Niedbalski, Z. (2008). Rock mass movements around development workings in various density of standing-and-roof-bolting support. Journal of Coal Science and Engineering (China), 14(3), 356-360. https://doi.org/10.1007/s12404-008-0078-1

16. Fabich, S., Bauer, J., Rajczakowska, M., \& Świtoń, S. (2015). Design of the shaft lining and shaft stations for deep polymetallic ore deposits: Victoria Mine case study. Mining Science, (22), 127146. https://doi.org/10.5277/msc152213

17. Bobek, R., Śledź, T., Twardokęs, J., Ratajczak, A., \& Głuch, P. (2016) Problemy stateczności obudowy szybów w świetle doświadczeń KWK Knurów-Szczygłowice. Zeszyty Naukowe Instytutu Gospodarki Surowcami Mineralnymi i Energia Polskiej Akademii Nauk, (94), 41-52.

18. PN-EN 12504-1:2009. (2009). Testing concrete in structures. Part 1. Cored specimens. Taking, examining and testing in compression. Comite Europeen de Normalisation.

19. PN-EN 12504-2:2002. (2002). Testing concrete in structures. Part 2. Non-destructive testing. Determination of rebound number.

20. PN-EN 12504-3:2006. (2006). Testing concrete in structures. Part 3. Determination of pull-out force.

21. PN-EN 12504-4:2005. (2005). Testing concrete in structures. Part 4. Determination of ultrasonic pulse.

22. Bock, S. (2006) Metody badań wytrzymałościowych obudowy szybów kopalnianych. Prace Naukowe GIG: Górnictwo i Środowisko, (3), 23-41.

23. Stasica, J. (2017). Nowoczesne metody badań i oceny stanu technicznego obudów szybów górniczych. Zeszyty Naukowe Instytutu Gospodarki Surowcami Mineralnymi i Energia PAN, (101), 85-99.

24. ROW Mine. (2018). Technical Documentation of the Shaft VII repair (unpublished). 